Vol 12, Issue 1, 2019

\title{
BIOFABRICATION OF ZINC OXIDE NANOPARTICLES USING PTEROCARPUS MARSUPIUM AND ITS BIOMEDICAL APPLICATIONS
}

\author{
SHYMALA RAJAN ABHINAYA, RAMAKRISHNAN PADMINI* \\ Department of Biochemistry, School of Life Sciences, Vels Institute of Science, Technology and Advanced Studies, Chennai, Tamil Nadu, India. \\ Email: padmini.sls@velsuniv.ac.in
}

Received: 24 July 2018, Revised and Accepted: 25 September 2018

\section{ABSTRACT}

Objective: The objective of the study is to perform the synthesis of zinc oxide nanoparticles using the bark extract of Pterocarpus marsupium and to evaluate its biomedical applications.

Methods: Various concentrations of zinc acetate are used, and synthesis conditions were optimized to get a stable nanoparticle. The finest synthesis condition for zinc oxide nanoparticle production was at pH 7 with $20 \mathrm{ml}$ extract, zinc acetate $10 \mathrm{mM}$, and 120 min of reaction time. The synthesized nanopowder was characterized using various analytical techniques, such as ultraviolet (UV)-visible spectroscopy, Fourier-transform infrared (FTIR) spectroscopy, X-ray diffraction (XRD), and scanning electron microscopy (SEM). The synthesized nanoparticles were tested for their antimicrobial, anti-inflammatory, inhibition of lipid peroxidation, and inhibition of amylase activity.

Results: The size range of nanoparticles obtained was in the range of 10-32 nm as reported by SEM. The UV-visible absorption spectrum of the synthesized nanoparticle showed a peak at $340 \mathrm{~nm}$, which confirmed the presence of nanoparticles. FTIR spectroscopy analysis indicated the presence of zinc oxide stretching at $666.22 \mathrm{~cm}^{-1}$. Further, the IR spectra indicated the presence of alcohols and acids, which can act as capping agents around the nanoparticles. XRD analysis confirmed the crystalline nature of nanoparticles.

The synthesized nanoparticle showed appreciable antimicrobial activity. Zinc oxide nanoparticles at $40 \mu \mathrm{g} /$ well were tested against phytopathogens, Pseudomonas aeruginosa, Staphylococcus aureus, Aspergillus flavus, and Aspergillus niger showed 16, 13, 15, and 16 mm zones of inhibition, respectively. The synthesized nanoparticle showed a considerable increase in inhibition of lipid peroxidation and amylase activity. The nanoparticle also exhibited appreciable anti-inflammatory activity measured by the inhibition of albumin denaturation.

Conclusion: The study instigates the simple and convenient method of synthesizing zinc oxide nanoparticles using $P$. marsupium and its few biomedical applications.

Keywords: Zinc oxide, Nanoparticles, Pterocarpus marsupium, Anti-inflammatory, Antimicrobial, Lipid peroxidation, Amylase inhibition.

(C) 2019 The Authors. Published by Innovare Academic Sciences Pvt Ltd. This is an open access article under the CC BY license (http://creativecommons. org/licenses/by/4. 0/) DOI: http://dx.doi.org/10.22159/ajpcr.2019.v12i1.28682

\section{INTRODUCTION}

Nanotechnology is the science about the synthesis of nanosized materials of variable size, shapes, chemical composition, and its potential use for human benefits [1-3]. The various types of nanoparticles include the metal nanoparticles, metal oxide nanoparticles, and polymer nanoparticles. Of these, the metal oxide nanoparticles comprise the most versatile one, owing to the metal oxide's stability, improved unique physical and chemical properties, and diversity in functionalities. Recently, nanotechnology has immense application in the field of life sciences and medical sciences with special emphasis on biomedical devices and as therapeutics [4]. Nanoparticles synthesized using physical and chemical methods are pure, well-defined but pose certain limitations such as environmental threats and high cost, whereas the biological methods are cost-effective and eco-friendly. The green synthesis of nanoparticles is achieved using plants and their derivatives and microorganisms such as bacteria, fungi, algae, and yeast. Pterocarpus marsupium Roxb., a plant belonging to Fabaceae, is traditionally used in ayurvedic system for the treatment of diabetes [5]. P. marsupium is, also commonly known as Malabar kino or Indian kino tree or Vijayasar., The plant is a medium-to-large, deciduous tree that can grow up to $30 \mathrm{~m}(98 \mathrm{ft}$ ) tall. It is indigenous to India, Nepal, and Sri Lanka. The plant exhibits many pharmacological activities that include hepatoprotective, antioxidant, antimicrobial, antidiabetic, and antiinflammatory activities $[5,6]$. The plant decreases the opacity index of the diabetic retina, thus proving its anticataract activity [7]. It reduces inflammation by inhibiting cyclooxygenase 2 and thus decreasing the prostaglandin 2 production [8]. So far the plant has not been subjugated for nanoparticle fabrication and its application. This study emphasizes the production, characterization, and few of its biomedical applications of green-synthesized zinc oxide nanoparticles using P. marsupium.

\section{METHODS}

\section{Collection of plant}

The plant material $P$. marsupium was collected in and around Chennai and authenticated by Dr. P. Jayaraman, Plant Anatomy Research Centre, Chennai, India (voucher specimen no: PARC/2017/3307).

\section{Preparation of zinc oxide nanoparticles using $\boldsymbol{P}$. marsupium}

Zinc oxide nanoparticles were synthesized using zinc acetate dihydrate $\mathrm{Zn}\left(\mathrm{CH}_{3} \mathrm{COO}\right)_{2} \cdot 2 \mathrm{H}_{2} \mathrm{O}$ as described previously by Gnanasangeetha and Thambavani 2013 [9] with slight modifications. Dried bark was ground to yield coarse powder, and $20 \mathrm{~g}$ of which was boiled in $100 \mathrm{ml}$ of doubledistilled water for $15 \mathrm{~min}$. The aqueous extract was then cooled, filtered using Whatman No.1 filter paper, and stored at $4^{\circ} \mathrm{C}$ for further use.

Synthesis and optimization of zinc oxide nanoparticles $20 \%$ aqueous extract with increasing concentrations of zinc acetate $(5,6,7,8,9$, and $10 \mathrm{mM})$ was used to optimize the synthesis. The 
mixture was heated constantly at $60^{\circ} \mathrm{C}$ with continuous stirring for $2 \mathrm{~h}$. The solution was then dried in oven at $60^{\circ} \mathrm{C}$. The concentration of $10 \mathrm{mM}$ zinc acetate was fixed, since complete conversion to zinc oxide nanoparticles takes place during drying at this $10 \mathrm{mM}$ concentration of zinc acetate. The synthesized zinc oxide nanopowder was stable even after 6 months.

\section{Characterization studies}

Optical properties of synthesized zinc oxide nanoparticle were characterized based on ultraviolet (UV) absorption spectra. The nanoparticles were diluted in deionized water $(0.1 \mathrm{mg} / \mathrm{ml})$, and the UV spectrum was recorded on Shimadzu UV-1800 spectrophotometer at the wavelength range of 200-500 $\mathrm{nm}$. Infrared (IR) spectra of synthesized nanoparticles were recorded on a Bruker series Fourier-transform IR (FTIR) spectrometer using $\mathrm{KBr}$ pellets. The spectra were obtained within the frequency range of $4000-500 \mathrm{~cm}^{-1}$. $\mathrm{X}$-ray diffraction (XRD) analysis was recorded on a Seifert 3000P $\mathrm{X}$-ray diffractometer operating at $30 \mathrm{kV}$ and $40 \mathrm{~mA}$. The pattern was recorded by $\mathrm{CuK} \alpha$ radiation with about $1.54060 \AA$ in steps of 0.02 , with $2 \theta$ scanning range from 10 to 80 . High-resolution scanning electron microscopy (SEM) was performed using JEOL 2100 field emission gun-based scanning electron high-solution microscope to analyze the nanoparticle shape and size.

\section{In vitro antibacterial and antifungal activity}

Bacteria, namely Pseudomonas aeruginosa and Staphylococcus aureus, were maintained at $4^{\circ} \mathrm{C}$ on nutrient agar slants. Overnight bacterial cultures grown in nutrient broth were adjusted to an inoculum size of $10^{8}$ cells $/ \mathrm{ml}$ for inoculation of the agar plates. An aliquot $(0.2 \mathrm{ml})$ of inoculum was added to the nutrient agar medium (HiMedia). The growth inhibition of bacteria by the nanoparticle was determined by the agar well diffusion assay as described by Kudi et al. [10]. Bacteria were maintained at $37^{\circ} \mathrm{C}$ on nutrient agar plates before use. Nutrient agar was prepared and $25 \mathrm{ml}$ each was poured into a sterile Petri dish. This was allowed to solidify and dry. Using a sterile cock borer of 8-mm diameter, three equidistant holes per plate were made in the agar and were inoculated with $0.2 \mathrm{ml}$ overnight suspension of the bacteria. The wells (holes) were filled with the synthesized nanoparticle solution at varying concentrations of $10 \mathrm{mg} / \mathrm{ml}, 5 \mathrm{mg} / \mathrm{ml}$, and $2.5 \mathrm{mg} / \mathrm{ml}$, respectively. The plates were incubated at $37^{\circ} \mathrm{C}$ for $24 \mathrm{~h}$. The experiments were repeated thrice. The antibacterial activities were observed and measured using a transparent meter rule and recorded if the zone of inhibition was $\geq 10 \mathrm{~mm}[10,11]$. The nanoparticles were also tested in a similar manner against fungal pathogens, namely Aspergillus flavus and Aspergillus niger.

\section{In vitro lipid peroxidation}

A modified thiobarbituric acid (TBA) reactive species assay was used to measure the lipid peroxide formed using liver homogenates as lipid-rich media, as described by Ruberto et al. [12]. Briefly, $0.5 \mathrm{ml}$ of liver homogenate $(10 \% \mathrm{v} / \mathrm{v})$ was added to $0.1 \mathrm{ml}$ of the synthesized zinc oxide nanoparticle $(10 \mu \mathrm{g} / \mathrm{ml})$. The volume was then made up to $1.0 \mathrm{ml}$ with distilled water. Thereafter, $0.05 \mathrm{ml}$ of FeSO 4 was added and the mixture was incubated at $37^{\circ} \mathrm{C}$ for $30 \mathrm{~min}$. Then, $1.5 \mathrm{ml}$ of acetic acid was added, followed by $1.5 \mathrm{ml}$ of TBA in sodium dodecyl sulfate. The resulting mixture was mixed thoroughly and heated at $95^{\circ} \mathrm{C}$ for $1 \mathrm{~h}$. After cooling, $5 \mathrm{ml}$ of butanol was added and the mixture was centrifuged at $3000 \mathrm{rpm}$ for $10 \mathrm{~min}$. The optical density of the organic upper layer was measured at $532 \mathrm{~nm}$. The percentage inhibition was calculated with the formula:

$\%$ inhibition of lipid peroxidation $=\left[\frac{100-\text { A sample }}{\text { A control }}\right] \times 100$

\section{Assay of alpha-amylase inhibition}

Alpha-amylase inhibitory activity of synthesized zinc oxide nanoparticle was analyzed by the method of Bernfeld, 1995 [13]. Briefly, $100 \mu \mathrm{l}$ of the synthesized zinc oxide nanoparticle was allowed to react with $200 \mu \mathrm{l}$ of $\alpha$-amylase enzyme and $100 \mu \mathrm{l}$ of $2 \mathrm{mM}$ phosphate buffer ( $\mathrm{pH}$ 6.9). After 20 -min incubation, $100 \mathrm{ml}$ of $1 \%$ starch solution was added. The same was performed for the control where $200 \mu$ of the enzyme was replaced by buffer. After incubation for $5 \mathrm{~min}, 500 \mu$ of the dinitrosalicylic acid reagent was added to both control and test. They were kept in a boiling water bath for $5 \mathrm{~min}$. The optical density was recorded at $540 \mathrm{~nm}$ using a spectrophotometer. The percentage inhibition of $\alpha$-amylase enzyme was calculated using the following formula

Inhibition $(\%)=100 \times\left[\right.$ Control $\left.-\frac{\text { Test }}{\text { Control }}\right]$

\section{Inhibition of albumin denaturation}

The synthesized compounds are screened for anti-inflammatory activity using inhibition of albumin denaturation technique, which was studied according to Mizushima and Kobayashi (1968) with slight modification [14]. The standard drug and synthesized nanoparticles dissolved in a minimum amount of dimethylformamide (DMF) and diluted with phosphate buffer $(0.2 \mathrm{M}, \mathrm{pH} 7.4)$. The final concentration of DMF in all solutions was $<2.5 \%$. Test solution ( $1 \mathrm{ml}$ ) containing different concentrations of nanoparticles was mixed with $1 \mathrm{ml}$ of $1 \mathrm{mM}$ albumin solution in phosphate buffer and incubated at $27^{\circ} \mathrm{C} \pm 1^{\circ} \mathrm{C}$ in BOD incubator for $15 \mathrm{~min}$. Denaturation was induced by keeping the reaction mixture at $60^{\circ} \mathrm{C} \pm 10^{\circ} \mathrm{C}$ in a water bath for $10 \mathrm{~min}$. After cooling, the turbidity was measured at $660 \mathrm{~nm}$ (UV-visible spectrophotometer, Shimadzu). Percentage of the inhibition of denaturation was calculated from the control where no drug was added. Each experiment was done in triplicate and the average was taken. The diclofenac sodium was used as standard drug.

\section{Statistical evaluation}

All results are expressed as mean $\pm \operatorname{SEM}(n=6)$. IC ${ }_{50}$ values were calculated by applying suitable regression analysis of the mean inhibitory values.

\section{RESULTS}

\section{IR spectra}

The IR spectra of of $P$. marsupium zinc oxide nanoparticles are shown in Fig. 1. The IR spectra are recorded in the mid-IR region within the range $\left(400-4500 \mathrm{~cm}^{-1}\right)$. The FT-IR spectra resulted in various peaks at $3298.92,2917.86,2113.41,1988.50,1932.31,1618.54,1423.48$, $1251.71,1020.33,767.23$, and $666.22 \mathrm{~cm}^{-1}$.

\section{UV visible spectra}

Fig. 2 represents the UV-visible absorption spectrum of $P$. marsipium $\mathrm{ZnO}$ nanoparticles. A strong absorption band at about $340 \mathrm{~nm}$ clearly demonstrates the presence of $\mathrm{ZnO}$ nanoparticles in the reaction mixture [15].

\section{XRD}

The XRD spectrogram of P. marsipium zinc oxide nanoparticles is shown in Fig. 3. The distinctive $\mathrm{ZnO}$ peaks with corresponding miller indices

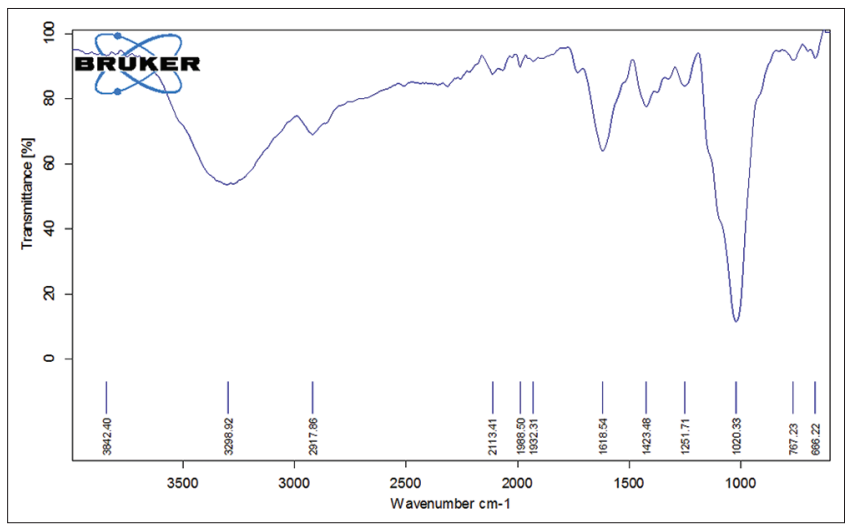

Fig. 1: Infrared spectrum of zinc oxide nanoparticles synthesized using Pterocarpus marsupium 


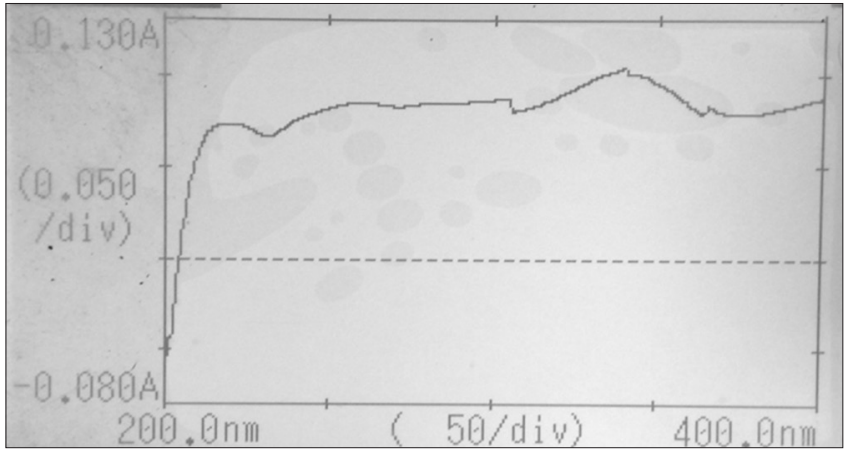

Fig. 2: Ultraviolet spectrum of zinc oxide nanoparticles synthesized using Pterocarpus marsupium

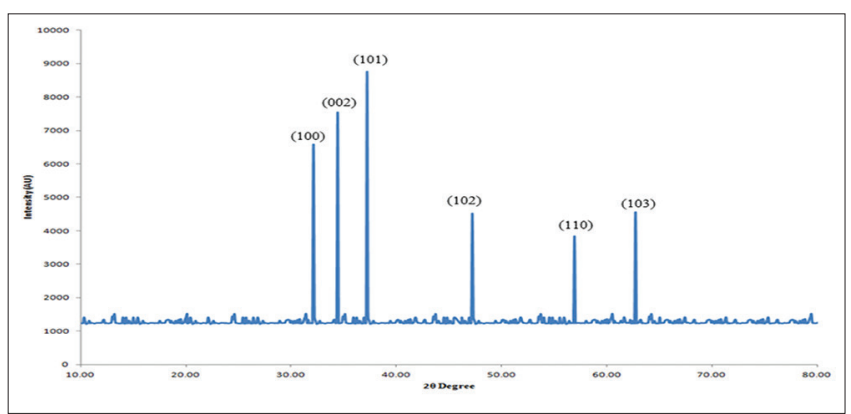

Fig. 3: X-ray diffraction spectrum of zinc oxide nanoparticles synthesized using Pterocarpus marsupium

are as follows at 32.90 (100), 34.5 (002), 36.33 (101), 47.50 (102), 57.25 (110), and 63.62 (103), respectively.

\section{SEM}

Fig. 4 represents the SEM pictures of $P$. marsipium $\mathrm{ZnO}$ nanoparticles at $\times 60,000$ magnifications. The SEM images confirm the formation of $\mathrm{ZnO}$ nanoparticles. The images also clearly substantiate the approximate spherical shape to the nanoparticles.

\section{Antimicrobial activity}

Tables 1 and 2 represent the antibacterial and antifungal activity of $P$. marsupium zinc oxide nanoparticles. The synthesized zinc oxide nanoparticles showed an appreciable antibacterial activity on $P$. aeruginosa and S. Aureus and antifungal activity on A. flavus and A. niger strains (Table 3 and Fig. 5)

\section{Effect on lipid peroxidation}

The synthesized $\mathrm{ZnO}$ nanoparticle demonstrated a considerable amount of lipid peroxidation inhibitory effect by $59.03 \%$, while butylated hydroxy anisole significantly inhibited lipid peroxidation by $64.43 \%$ at the concentration of $100 \mu \mathrm{g} / \mathrm{ml}$. The results were concentration dependent as depicted in Tale 3 . The $\mathrm{IC}_{50}$ was found to be 177.53 for synthesized zinc oxide nanoparticles.

\section{Effect on amylase inhibition}

Table 4 represents the amylase inhibitory activity by P. marsupium zinc oxide nanoparticles. The percentage inhibition of alpha-amylase by the $\mathrm{ZnO}$ nanoparticle synthesized using $P$. marsupium was studied in a concentration range of $20-100 \mu \mathrm{g} / \mathrm{ml}$, and the $\mathrm{IC}_{50}$ was found to be 59.38 .

\section{Effect on protein denaturation}

The in vitro anti-inflammatory activity of $P$. marsupium zinc oxide nanoparticle on inhibiting denaturation of proteins is clearly depicted in Table 5. The minimum inhibition by the synthesized nanoparticles is $20.20 \pm 1.18 \%$ observed at the concentration of $20 \mu \mathrm{g} / \mathrm{ml}$. The $\mathrm{IC}_{50}$ was found to be 98.45 .
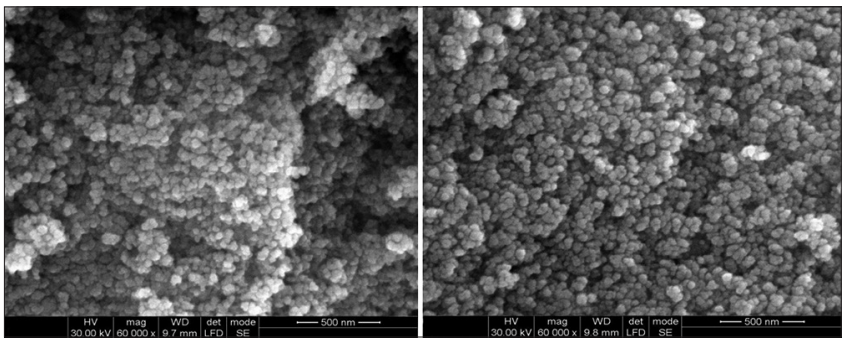

Fig. 4: Scanning electron micrograph of zinc oxide nanoparticles synthesized using Pterocarpus marsupium
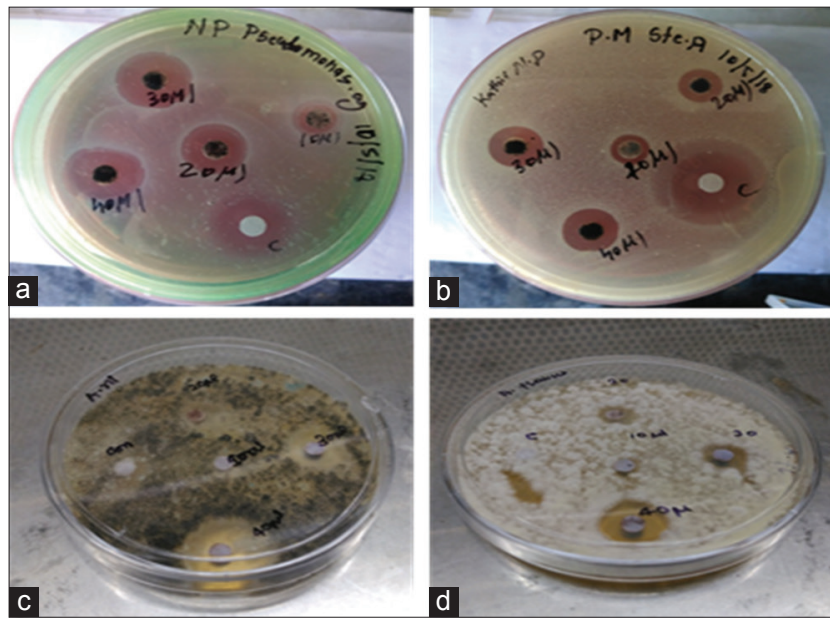

Fig. 5: Antibacterial and antifungal activity of zinc oxide nanoparticles synthesized using Pterocarpus marsupium.

Bacterial strains - (a) Pseudomonas aeruginosa and

(b) Staphylococcus aureus; Fungal strains - (c) Aspergillus niger and (d) Aspergillus flavus

\section{DISCUSSION}

\section{IR spectrum}

FT-IR spectroscopy helps to establish the identity of various phytochemical constituents involved in the reduction and stabilization of the nanoparticles. In this study, the peak around $3298.92 \mathrm{~cm}^{-1}$ corresponds to alcohols $(\mathrm{O}-\mathrm{H})$. The peaks at 2917.86 and $2113.41 \mathrm{~cm}^{-1}$ denote SP 3 carbon-hydrogen/alkyl (C-H). The peaks at $2113.41 \mathrm{~cm}^{-1}$ correspond to alkyne $(\mathrm{C} \equiv \mathrm{C})$ group. The peak at $1618.54 \mathrm{~cm}^{-1}$ denotes alkene $(\mathrm{C}=\mathrm{C})$.

The absorption peaks in the range of $400-700 \mathrm{~cm}-1$ are attributed to the $\mathrm{ZnO}$ stretching modes. Depending on the synthesis and other experimental conditions, weak bands for zinc oxide are positioned at $520 \mathrm{~cm}^{-1}, 566 \mathrm{~cm}^{-1}$, and $665 \mathrm{~cm}^{-1}[16,17]$. A peak at $666.22 \mathrm{~cm}^{-1}$ obtained in this study is suggestive of zinc oxide stretching.

\section{UV-visible spectrum}

UV spectrum is widely being used to examine the optical properties of nanosized particles. Conducting electrons begin oscillating at a certain wavelength range due to surface plasmon resonance effect. In this study, an absorption peak is observed at $340 \mathrm{~nm}$. This result is in concordance with report of Elizabeth Varghese and Mary George, 2015, where the blue shift in the absorption spectrum at $340 \mathrm{~nm}$ is suggestive of the formation of zinc oxide nanoparticles [15]

\section{XRD}

The $2 \theta$ values obtained in this study are exactly located at $34.52^{\circ}$, $36.33^{\circ}, 47.5^{\circ}$, and $63.6^{\circ}$. The spectrum is comparable to the hexagonal Wurtzite phase of zinc oxide [18,19] (JPCDS card number: 36-1451). 
Table 1: Antifungal activity of Pterocarpus marsupium zinc oxide nanoparticles

\begin{tabular}{lllll}
\hline Organism & Positive control & $\mathbf{4 0} \boldsymbol{\mu g}$ & $\mathbf{1 0} \boldsymbol{\mu g}$ & Negative control (zinc acetate alone) \\
\hline Aspergillus flavus & 21 & 16 & 7 & 10 \\
Aspergillus niger & 19 & 13 & 6 & 10 \\
\hline
\end{tabular}

Table 2: Antibacterial activity of Pterocarpus marsupium zinc oxide nanoparticles

\begin{tabular}{lllll}
\hline Organism & Positive control & $\mathbf{4 0} \boldsymbol{\mu g}$ & $\mathbf{1 0} \boldsymbol{\mu g}$ & Negative control (zinc acetate alone) \\
\hline Escherichia coli & 20 & 15 & 7 & 10 \\
Pseudomonas aeruginosa & 21 & 16 & 7 & 10 \\
\hline
\end{tabular}

Table 3: In vitro lipid peroxidation by Pterocarpus marsupium zinc oxide nanoparticles

\begin{tabular}{llll}
\hline Treatment & Concentration & \% inhibition & $\mathbf{I C}_{\mathbf{5 0}}$ \\
\hline Pterocarpus marsupium & 20 & $21.0 \pm 1.15$ & 177.53 \\
zinc oxide nanoparticles & 40 & $36.6 \pm 0.89$ & \\
& 60 & $45.0 \pm 1.53$ & \\
& 80 & $51.33 \pm 1.66$ & \\
BHA & 100 & $59.03 \pm 0.92$ & \\
& 20 & $25.7 \pm 1.27$ & 78.49 \\
& 40 & $32.2 \pm 1.54$ & \\
& 60 & $45.5 \pm 1.31$ & \\
& 80 & $54.4 \pm 1.77$ & \\
& 100 & $64.4 \pm 1.85$ & \\
\hline
\end{tabular}

Values are expressed in terms of mean \pm Standard Error of Mean $(n=6)$. BHA: Butylated hydroxy anisole.

Table 4: Amylase inhibitory activity by Pterocarpus marsupium zinc oxide nanoparticles

\begin{tabular}{llll}
\hline Treatment & Concentration & \% inhibition & IC $_{\mathbf{5 0}}$ \\
\hline Pterocarpus marsupium & 40 & $33.36 \pm 1.31$ & 59.38 \\
zinc oxide nanoparticles & 60 & $44.93 \pm 1.83$ & \\
& 80 & $56.03 \pm 1.62$ & \\
Acarbose & 100 & $59.23 \pm 1.61$ & \\
& 20 & $21.0 \pm 1.05$ & 218.49 \\
& 40 & $30.76 \pm 1.76$ & \\
& 60 & $42.73 \pm 1.61$ & \\
& 80 & $52.36 \pm 1.88$ & \\
& 100 & $64.26 \pm 2.12$ & \\
\hline
\end{tabular}

Values are expressed in terms of mean \pm Standard Error of Mean $(n=6)$.

Table 5: Inhibition of protein denaturation by Pterocarpus marsupium zinc oxide nanoparticles

\begin{tabular}{llll}
\hline Treatment & Concentration & \% inhibition & IC $_{\mathbf{5 0}}$ \\
\hline Pterocarpus marsupium & 20 & $20.20 \pm 1.18$ & 98.45 \\
zinc oxide nanoparticles & 40 & $36.23 \pm 1.15$ & \\
& 60 & $48.53 \pm 1.48$ & \\
& 80 & $56.33 \pm 1.24$ & \\
Diclofenac sodium & 100 & $64.63 \pm 1.50$ & \\
& 20 & $13.83 \pm 1.07$ & 167.23 \\
& 40 & $36.56 \pm 1.41$ & \\
& 60 & $59.43 \pm 1.56$ & \\
& 80 & $73.3 \pm 1.76$ & \\
& 100 & $90.83 \pm 2.02$ & \\
\hline
\end{tabular}

Values are expressed in terms of mean \pm Standard Error of Mean $(n=6)$.

\section{SEM}

The synthesized zinc oxide nanoparticles are spherical in shape, and most of the particles exhibit some faceting. This spherical shape is similar to the reports of Raj and Jayalashmi, 2015 [20].

\section{Antimicrobial activity}

Antimicrobial activity of $\mathrm{ZnO}$ nanoparticles against various pathogens such as Bacillus subtilis, Salmonella, Listeria monocytogenes, S. aureus, and Escherichia coli using disc diffusion method has been reported [21,22]. The antimicrobial activity of $P$. marsupium is also well documented [23]. In this study, the zones of inhibition recorded (in $\mathrm{mm}$ ) for P. aeruginosa, S. aureus, A. flavus, and A. niger are 16, 13, 15 , and 16 at $40 \mu \mathrm{g} / \mathrm{ml}$ well, respectively (Fig. 5), suggesting that P. marsupium synthesized zinc oxide nanoparticles are also effective in culminating the microbial growth. Some of the proposed mechanisms of antibacterial activity by the zinc oxide nanoparticles include the disruption of the cell membrane, oxidative stress induction and generation of reactive oxygen species, $\mathrm{Zn++}$ release, internalization of $\mathrm{ZnO}$ NPs into bacteria, and electrostatic interactions as reported by Sirelkhatim et al., 2015 [24].

\section{Inhibition of lipid peroxidation}

Lipid peroxidation is the process by which the free radicals obtain electrons from the lipids in cell membranes and cause the oxidative degradation of lipids culminating in cell damage. In this study, the peroxidation of liver phospholipid extract was induced by ferric chloride. The hydroxyl radicals formed during the reaction interact with biological membranes, leading to the formation of malondialdehyde and other aldehydes that form a pink chromogen with TBA, showing strong absorbance at $532 \mathrm{~nm}$. In this study, $P$. marsupium synthesized zinc oxide nanoparticles showed an appreciable effect on the inhibition of lipid peroxidation. Furthermore, P. marsupium has been reported to have antioxidant property $[5,23]$. The phenolic compounds in the plant extract may suppress lipid peroxidation through different chemical mechanisms, including free radical quenching, electron transfer, radical addition, or radical recombination [25], thus suggesting its role in inhibition of lipid peroxidation.

\section{Amylase inhibition}

Alpha-amylase is an enzyme involved in starch breakdown, and the inhibition of amylase activity is a further therapeutic target in controlling type II diabetes. Plant-based $\alpha$-amylase inhibitors control the rate of digestion and absorption of carbohydrates [26]. Zinc oxide nanoparticles as possible alpha-amylase inhibitors have well been documented, wherein the optimum dose of $20 \mu \mathrm{g} / \mathrm{ml}$ was sufficient to exhibit $49 \%$ glucose inhibition at neutral $\mathrm{pH}$ and $35^{\circ} \mathrm{C}$ temperature [27].

\section{Inhibition of protein denaturation}

Denaturation of protein means loss of biological properties of protein molecules, its structure as well its function. Protein denaturation is a consequence of inflammation. Production of autoantigens in certain arthritic diseases may be due to the denaturation of proteins in vivo $[28,29]$. Drugs or phytochemicals which are helpful in preventing protein denaturation are promising anti-inflammatory therapeutics [30]. The antiinflammatory effects are mediated by phenolics and flavonoids present in the plant extracts [31]. In this study, we observed a dose-dependent inhibition of protein denaturation by the zinc oxide nanoparticles. This is suggestive of its anti-inflammatory effect. The ability to inhibit protein 
denaturation is indirectly serving the ailment to mitigate, and this could serve as a target for anti-inflammatory drug development.

\section{CONCLUSION}

The method used for the synthesis of zinc oxide nanoparticle using P. marsupium is both energy and cost-effective with a high particle yield at lower concentration of plant extract. The synthesized nanoparticles are highly stable. The FTIR spectrum showed the $\mathrm{ZnO}$ stretching at $666 \mathrm{~cm}^{-1}$ and the optical property measured by UV spectroscopy with absorption peak maximum at $340 \mathrm{~nm}$. XRD confirmed the crystalline nature of nanoparticles. The morphology of synthesized nanoparticles assessed by SEM clearly enunciates its spherical nature with size ranging from 10 to $32 \mathrm{~nm}$. The synthesized nanoparticle was further studied for few biomedical applications. The nanoparticles showed appreciable antimicrobial activity. The in vitro inhibition of amylase activity, albumin denaturation, and lipid peroxidation by the synthesized $\mathrm{ZnO}$ nanoparticle makes it a potential therapeutic against inflammation disorders.

\section{CONFLICTS OF INTEREST}

They have no conflicts of interest.

\section{AUTHORS' CONTRIBUTION}

(1) Shymala Rajan Abhinaya performed the experiments presented in this study. (2) Ramakrishnan Padmini devised the concept and plan of the study, interpretation of the data obtained, and preparation of the manuscript.

\section{REFERENCES}

1. Colvin VL, Schlamp MC, Alivisatos A. Light emitting diodes made from cadmium selenide nanocrystals and a semiconducting polymer. Nature 1994;370:354-57.

2. Wang Y, Herron N. Nanometer-sized semiconductor clusters: Materials synthesis, quantum size effects, and photophysical properties. J Phys Chem 1991;95:525-32.

3. Schmid G. Large clusters and colloids. Metals in the embryonic state. Chem Rev 1992;92:1709-27.

4. Hoffman AJ, Mills G, Yee H, Hoffmann M. Q-sized cadmium sulfide: Synthesis, characterization, and efficiency of photoinitiation of polymerization of several vinylic monomers. J Phys Chem 1992;96:5546-52.

5. Abhishek N, Hegde K. Pharmacological profile of Pterocarpus marsupium with a note on its therapeutic activity. Int J Pharm Clin Res 2017;3 Suppl 1:32-7.

6. Manikani KL, Krishna V, Manjunatha BK, Vidya SM, Singh SD, Manohara YN, et al. Evaluation of hepatoprotective activity of stem bark of Pterocarpus marsupium Roxb. Indian J Pharmacol 2005;37 Suppl 3:165-8.

7. Vats V, Yadav SP, Biswas NR, Grover JK. Anti-cataract activity of Pterocarpus marsupium bark and Trigonella foenumgraecum seeds extract in alloxan diabetic rats. J Ethnopharmacol 2004;93 Suppl 2-3:289-94.

8. Hougee S, Faber J, Sanders A, Dejong RB, Vandenberg WB, Garssen J, et al. Selective COX-2 inhibition by a Pterocarpus marsupium extract characterized by pterostilbene, and its activity in healthy human volunteers. Planta Med 2005;71 Suppl 5:387-92.

9. Gnanasangeetha D, Thambavani SD. Biogenic production of zinc oxide nanoparticles using Acalypha indica. J Chem Biol Phys Sci
2014;4 Suppl 1:238-46.

10. Kudi AC, Umoh JU, Eduvic LO, Getu J. Screening of some Nigerian medicinal plants for antibacterial activity. J Ethnopharmacol 1999;67:225-8.

11. Vlietink AJ, Van Hoof L, Totte J, Laure H, Vanden Berhe D, Rwangabo PC, et al. Screening of hundred rwandese medical plants for antimicrobial and antiviral properties. J Ethnopharmacol 1995;46:31-47.

12. Ruberto G, Baratta MT, Deans SG, Dorman HJ. Antioxidant and antimicrobial activity of Foeniculum vulgare and Crithmum maritimum essential oils. Planta Med 2000;66:687-93.

13. Bernfeld P. Amylases, $\alpha$ and $\beta$. Methods Enzymol 1955;1:149-58.

14. Mizushima Y, Kobayashi M. Interaction of anti-inflammatory drugs with serum preoteins, especially with some biologically active proteins. J Pharm Pharmacol 1968;20:169-173.

15. Varghese E, George M. Green synthesis of zinc oxide nanoparticles. Int J Adv Res Sci Eng 2015;4 Suppl 1:307-14

16. Djaja N, Montja D, Saleh R. The effect of Co incorporation into $\mathrm{ZnO}$ nanoparticles. Adv Mater Phys Chem 2013;3 Suppl 1:33-41.

17. Hernández A, Maya L, Sánchez-Mora E, Sánchez EM. Sol-gel synthesis, characterization and photocatalytic activity of mixed oxide $\mathrm{ZnO}-\mathrm{Fe}_{2} \mathrm{O}_{3}$. J Solgel Sci Technol 2007;42 Suppl 1:71-8.

18. Zhou J, Zhao F, Wang Y, Zhang Y, Yang L. Size-controlled synthesis of $\mathrm{ZnO}$ nanoparticles and their photoluminescence properties. J Lumin 2007;122-3 Suppl 1-2:195-7.

19. Khoshhesab ZM, Sarfaraz M, Asadabad MA. Preparation of zno nanostructures by chemical precipitation method. Synth React Inorg Met Org Nano Met Chem 2011;41 Suppl 7:814-9.

20. Raj LF, Jayalakshmy E. A biogenic approach for the synthesis and characterization of zinc oxide nanoparticles produced by Tinospora cordifolia. Int J Pharm Pharm Sci 2015;7 Suppl 8:384-6.

21. Fowsiya J, Madhumitha G, Al-Dhabi NA, Arasu MV. Photocatalytic degradation of Congo red using Carissa edulis extract capped zinc oxide nanoparticles. J Photochem Photobiol B 2016;162:395-401.

22. Dobrucka R, Długaszewska J. Biosynthesis and antibacterial activity of $\mathrm{ZnO}$ nanoparticles using Trifolium pratense flower extract. Saudi J Biol Sci 2016;23:517-23

23. Deepa R, Manjunatha H, Krishna V, Swamy BE. Evaluation of antimicrobial activity and antioxidant activity by electrochemical method of ethanolic extract of Pterocarpus marsupium Roxb bark. J Biotechnol Biomater 2014:4:166-9.

24. Sirelkhatim A, Mahmud S, Seeni A, Kaus NH, Ann LC, Bakhori SK, et al. Review on zinc oxide nanoparticles: Antibacterial activity and toxicity mechanism. Nano Micro Lett 2015;7 Suppl 3:219-42.

25. Hodges DM, DeLong JM, Forney CF, Prange RK. Improving the thiobarbituric acid-reactive-substances assay for estimating lipid peroxidation in plant tissues containing anthocyanin and other interfering compounds. Planta 1999;207:604-11.

26. Musa MY, Griffith AM, Michels AJ, Schneider E, Frei B. Inhibition of $\alpha$-amylase and $\alpha$-glucosidase activity by tea and grape seed extracts and their constituent catechins. J Agric Food Chem 2012;60:8924-9.

27. Dhobale S, Thite T, Laware SL, Rode CV, Koppikar SJ, Ruchika-Kaul $\mathrm{G}$, et al. Zinc oxide nanoparticles as novel alpha-amylase inhibitors. J App Phys 2008;104:94907.

28. Leelaprakash G, Dass SM. In vitro antiinflammatory activity of methanol extract of Enicostemma axillare. Int J Drug Dev Res 2010;3:189-96.

29. Ingle PV, Patel DM. C-reactive protein in various disease condition-an overview. Asian J Pharm Clin Res 2011;4 Suppl 1:9-13

30. Phongpradist R, Chaiyana W, Anuchapreeda S. Curcumin-loaded multi-valent ligands conjugated-nanoparticles for anti-inflammatory activity. Int J Pharm Pharm Sci 2015;7 Suppl 4:203-8.

31. Sangeetha G, Vidhya R. In vitro anti-inflammatory activity of different parts of Pedalium murex (L.) Int J Herb Med 2016;4 Suppl 3:31-6. 